\title{
Recognition of Candida albicans and Role of Innate Type 17 Immunity in Oral Candidiasis
}

\author{
Anna Pavlova ${ }^{1}$ and Irshad Sharafutdinov ${ }^{2, *(1)}$ \\ 1 Integrated Immunology Programme, Division of Genetics, Department of Biology, Friedrich Alexander \\ University Erlangen-Nuremberg, 91058 Erlangen, Germany; anna.pavlova@fau.de \\ 2 Division of Microbiology, Department of Biology, Friedrich Alexander University Erlangen-Nuremberg, \\ 91058 Erlangen, Germany \\ * Correspondence: irshad.sharafutdinov@fau.de
}

Received: 1 August 2020; Accepted: 1 September 2020; Published: 2 September 2020

\begin{abstract}
Candida albicans is an opportunistic pathogenic fungus considered to be a common member of the human microflora. Similar to some other opportunistic microbes, C. albicans can invade and benefit from its host when the immune status of that host is weakened. Most often this happens to immunocompromised individuals, leading to the infection of oral and vaginal mucosae or the systemic spread of the pathogen throughout the entire body. Oropharyngeal candidiasis (OPC) occurs in up to 90 percent of patients with acquired immunodeficiency syndrome (AIDS), making it the most frequent opportunistic infection for this group. Upon first signs of fungal invasion, a range of host signaling activates in order to eliminate the threat. Epithelial and myeloid type cells detect $C$. albicans mainly through receptor tyrosine kinases and pattern-recognition receptors. This review provides an overview of downstream signaling resulting in an adequate immune response through the activation of various transcription factors. The study discusses recent advances in research of the interleukin-17 (IL-17) producing innate cells, including natural T helper 17 (nTh17) cells, $\gamma \delta$ T cells, invariant natural killer T (iNKT) cells and type 3 innate lymphoid cells (ILC3) that are involved in response to oral $C$. albicans infections.
\end{abstract}

Keywords: Candida albicans; innate immunity; IL-17; receptor tyrosine kinase; $\gamma \delta$ T cells; natural Th17 cells; iNKT; ILC3

\section{Introduction}

The oral environment is characterized by a complex microflora consisting of fungal and bacterial species tightly coexisting with each other [1]. These two major microbial groups can have both synergistic and antagonistic interactions therefore suppression of one group can affect the growth possibilities for another [2]. Candida albicans can play a protective function for bacteria as has recently been reported for the dual-species infection C. albicans and a periodontal pathogen Porphyromonas gingivalis [3]. In contrast, treatment of the denture stomatitis patients with probiotic Streptococcus salivarius strain reduced clinical signs and symptoms of infection and the count of $C$. albicans, keeping the effect for at least 30 days [4]. Among all fungal microbes isolated from clinical specimens, the most frequently found species is C. albicans $[5,6]$. This microorganism is a common member of the human microbiota for at least half of the human population [7,8]. C. albicans is a highly adaptive microorganism, with the ability to transform between yeast and hyphal forms being one of its major virulence factors $[9,10]$. When C. albicans transforms from yeast to hyphal state, its cell wall undergoes constitutional changes, decreasing the recognition of the pathogen by the host immune system [11,12]. Under certain conditions, C. albicans can cause a range of opportunistic diseases, predominantly in immunocompromised patients $[13,14]$. Classical factors predisposing 
individuals to C. albicans invasion include treatment with broad-spectrum antibiotics, antineoplastic and immunosuppressive treatment, and organ transplantation [15]. In the acquired immunodeficiency syndrome (AIDS) patients, Candida was found to be the only fungi isolated from oral mucosal swabs, while in healthy people, mycobiota are more diversified and may include Cladosporium, Aspergillus, Fusarium, Penicillium and other genera with Candida accounting for around only 20\% [16,17]. In general, human immunodeficiency virus (HIV) infected patients have oropharyngeal candidiasis (OPC) as the most common oral manifestation [18-20]. Even though much progress has been made over the last two decades in the development of antiretroviral therapy, 38\% out of 37.9 million HIV infected patients still have no access to these life-saving medications, making OPC a common disorder for millions of people [21]. When C. albicans switches its behavior from benign commensal to aggressive invasion of the epithelial layer, the innate immune system is the first to be activated [22]. The signaling cascade starts from the host-pathogen contact in epithelial cells, following with the interleukin-17 (IL-17)-dependent recruitment of phagocytic cells, such as neutrophils, macrophages, and dendritic cells (DCs) to the site of infection [23,24]. Phagocytes kill fungal cells both intracellularly and extracellularly via oxidative (reactive oxygen species) and nonoxidative mechanisms (hydrolytic enzymes and antimicrobial peptides), which are then followed by adaptive immunity [22,25]. Interestingly, in addition to phagocytosis, neutrophils can constrain the growth of $C$. albicans with neutrophil extracellular traps (NETs) containing calprotectin, an antifungal peptide [26,27]. The main source of IL-17 in humans are T helper 17 (Th17) cells, whereas in mice it is mainly produced by $\gamma \delta \mathrm{T}$ cells and natural Th17 (nTh17) cells [28]. Besides $\gamma \delta \mathrm{T}$ cells and nTh17, there are other IL-17 producing cells, including invariant natural killer T (iNKT) cells and innate lymphoid cells (ILCs), which altogether present type 17 cells [29-31]. It is noteworthy that IL-17 dependent immunity in oral candidiasis is considered as a key response to eliminate infection. In vaginal candidiasis, however, its role remains controversial [32-34]. In this review, initial pathogen recognition by oral epithelial as well as myeloid cells will be first described. The following role of IL-17 producing innate $\gamma \delta \mathrm{T}$ cells, nTh17, iNKT, and ILC3 cells will be then summarized.

\section{How Does C. albicans Invasion Trigger IL-17 Production?}

Organization of the C. albicans cell wall is important to understand how this microorganism can be recognized by the host immune system. The cell wall of $C$. albicans consists of two major layers, which define the fungal structure and antigenic properties. The inner $\beta$-glucan-chitin skeleton is responsible for the strength and shape of the cell wall. Chitin is located in the inner layer of the cell wall, while $\beta$-1,6-glucans are linked to $\beta$-1,3-glucans, connecting the inner and outer cell wall $[35,36]$. The outer layer of $C$. albicans is covered by cell wall proteins which are N- and/or O- glycosylated with mannose-containing carbohydrates (mannans). Outer mannoproteins are cross-linked to the inner $\beta$-1,6-glucans through a glycosylphosphatidylinositol (GPI) remnant [37]. Altogether $\beta$-glucans, mannans as well as nucleic acids of $C$. albicans, form a group of so-called pathogen- associated molecular patterns (PAMPs) [38,39]. Identification of nonself molecules via PAMPs can occur by pattern-recognition receptors (PRRs) in both epithelial and myeloid cells. PRRs consist of three major classes: Toll-like receptors (TLRs), C-type lectin receptors (CLRs) and nucleotide-binding oligomerization domain-like (NOD-like) receptors (NLRs) [38,40].

However, the molecular basis of pathogen recognition and signal transduction upon C. albicans infection differs in epithelial and myeloid cells. In general, the response to $C$. albicans begins with the activation of (1) receptor tyrosine kinases (RTKs), mainly in epithelia, and (2) PRRs predominantly in myeloid cells (Figure 1). Activated receptors subsequently trigger molecular signaling to transcription factors resulting in cytokines/chemokines release. In addition, activated receptors can initiate secretion of antimicrobial peptides, such as cathelicidin LL-37, histatins, and defensins, suppressing pathogen growth $[38,41]$. 


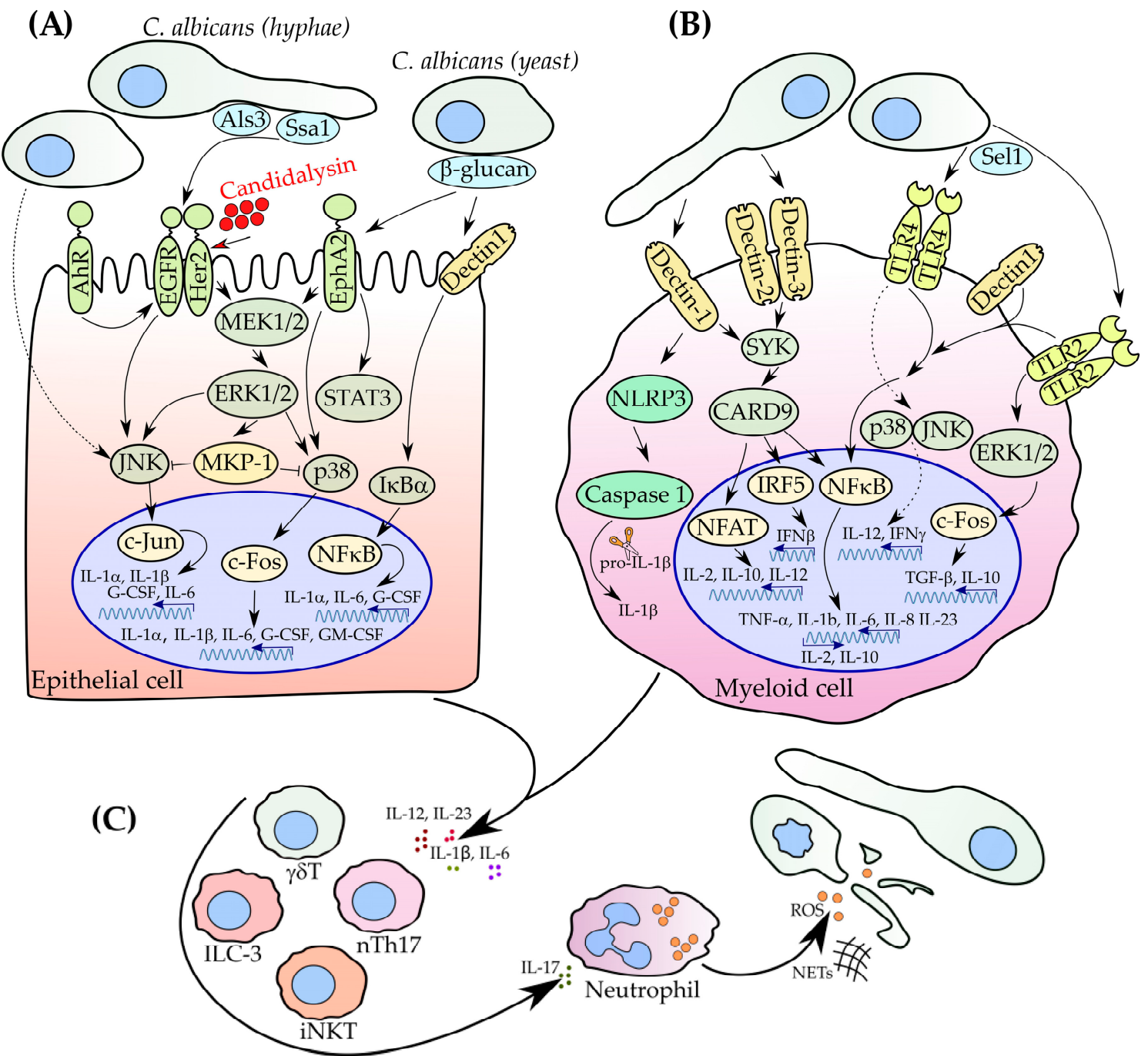

Figure 1. Schematic overview of molecular pathways in response to C. albicans which lead to the interleukin-17 (IL-17)-dependent neutrophil recruitment. (A) Upon C. albicans invasion, epithelial cells recognize fungal pathogen mainly via receptor tyrosine kinases (RTKs) such as epidermal growth factor receptor (EGFR) and human epidermal growth factor receptor 2 (Her2). Phosphorylation events lead to the downstream signaling cascade resulting in the activation of transcription factors and subsequent release of cytokines and chemokines. (B) Immune cells of myeloid nature, such as macrophages and dendritic cells (DCs), recognize C. albicans mainly via pathogen-associated molecular patterns (PAMPs) recognition by pattern-recognition receptors (PRRs) (key receptors here are dectin-1 and Toll-like receptors 2/4 (TLR2/4)). (C) Activated type 17 cells produce IL-17 to recruit neutrophils to the site of pathogen invasion. Neutrophils release reactive oxygen species (ROS) molecules and neutrophil extracellular traps (NETs) and provide the host cells protection, especially during the first hours of infection.

\subsection{Role of Myeloid Cells in Pathogen Recognition}

Myeloid cells, such as macrophages and DCs, mainly respond to C. albicans through PRRs recognition of respective PAMPs. CLR family members dectin- 1 and dectin-2/3 participate in recognition of $C$. albicans by binding to fungal $\beta$-glucans and $\alpha$-mannans, respectively [42,43]. Dectin 1 is mainly expressed on monocytes and macrophages, while Dectin 2 is expressed on dendritic cells (DCs), macrophages, and neutrophils $[44,45]$. After binding to the ligands, dectins recruit the spleen tyrosine kinase (SYK) via their tyrosine-based motifs [46,47]. Caspase recruitment domain 9 (CARD9) protein is a key transducer of Dectin-1 signaling for activation of myeloid cells, cytokine production, and innate 
antifungal immunity $[42,45,48]$. The downstream signaling leads to activation of the nuclear factor kappa-light-chain-enhancer of activated B cells (NF- $\mathrm{kB}$ ), whereby coordinating the induction of tumor necrosis factor (TNF), interleukin (IL)-1 $\beta$, IL-6, and IL-23 in DCs and macrophages [43,47,49]. Alternatively, downstream signaling from dectin-1 to SYK and CARD9 can activate the interferon response factor 5 (IRF5), resulting in interferon $\beta$ production. Dectin- 1 was also shown to activate the nuclear factor of activated T-cells (NFAT) transcription factor, resulting in the production of IL-2, IL-10, and IL-12 p70 by both macrophages and dendritic cells [50,51]. In mucosal candidiasis, dectin-1 can induce a robust production of the p19 chain of IL-23 and a low induction of the p35 chain of IL-12. However, this was shown to be dependent on host genetic background [52]. IL-23p19(-/-) mice with impaired Th17 response developed severe OPC and diminished neutrophil recruitment, while Th1-deficient IL-12p35(-/-) mice countered infection, assuming a dispensable role of Th1 response during OPC [24]. Since IL-12 and IL-23 heterodimers share a common p40 chain, dectin 1-dependent p19 production can presumably define Th17 differentiation. Interestingly, C. albicans can escape from dectin-1 recognition via masking $\beta$-glucans with cell wall mannoproteins, which causes the delay of fungal uptake by phagocytes, allowing hyphal extension [12]. This mechanism is also well established in another fungal pathogen, Aspergillus fumigatus, which also displays stage-specific $\beta$-glucan exposure to dectin-1 [53]. Furthermore, in response to $C$. albicans both dectins 1 and 2 were shown to activate host cytosolic phospholipase A2 ( $\left.\mathrm{CPLA}_{2} \alpha\right)$, following with the production of arachidonic acid metabolites, such as prostaglandins $[54,55]$. Prostaglandins are potent lipid molecules playing a pivotal role in the modulation of immunity [56,57]. Intriguingly, C. albicans is able to produce prostaglandins itself de novo or via conversion of exogenous arachidonic acid, thereby amplifying downstream signaling [58,59]. It was shown that fungal prostaglandins can inhibit TNF- $\alpha$ and induce IL-10 production, which can enhance fungal-cell adhesion, germ-tube development, and biofilm formation by C. albicans [58,60-62]. Other important CLRs recognizing fungal mannans include mannose receptor, DC-specific ICAM3-grabbing non-integrin (DC-SIGN), and macrophage-inducible C-type lectin (MINCLE) [63]. Altogether, CLRs compose a major group of PRRs providing a strong proinflammatory response, which provides initial host protection. On the other hand, TLR2 and TLR4 can recognize fungal O-linked mannoproteins and phospholipomannans, respectively. This leads to the activation of NF- $\mathrm{KB}$ and mitogen-activated protein kinases (MAPKs), such as c-Jun N-terminal kinase (JNK), extracellular signal-regulated kinase (ERK) and MAPK p38 (p38), which induce a strong proinflammatory cytokine response [64-66]. As it has been shown by in vitro studies, the production of proinflammatory cytokines in response to yeast and hyphal C. albicans in macrophages is likely dependent on TLR2 signaling, while TLR4 seems to have a minor role in recognition of this pathogen $[65,67]$. However, other researchers have demonstrated that both TLR2 and TLR4 are equally important in mediating immune response to C. albicans, presenting different points of view in this regard [68-70]. Recently, C. albicans has been shown to upregulate expression of its small secreted cysteine-rich protein Sel1, and both TLR2 and TLR4 were required for its recognition [69]. In addition, NOD-, LRR- and pyrin domain-containing 3 (NLRP3) can recognize fungal hyphae (but not yeasts) leading to caspase-1 mediated mature IL-1 $\beta$ production [71,72]. Interestingly, C. albicans peptide toxin candidalysin was found to trigger both NLRP3 inflammasome response and inflammasome-independent cytolysis of macrophages and dendritic cells [73,74]. Complement system and pattern-recognition molecules (PRMs) also play important roles in innate immune defense against $C$. albicans $[75,76]$. All main pathways of the complement system, including classical, lectin, and alternative pathways, have been reported to be activated in response to this microbe [76]. C3 fragments opsonize C. albicans and enhance the uptake of the pathogen by complement receptor-bearing phagocytes via CR3. Among the PRMs, members of the pentraxin superfamily have been shown to be implicated in anti-fungal immunity [77]. Pentraxin 3 (PTX3) belongs to the long pentraxins and can be secreted by monocytes, macrophages, and dendritic cells in response to TNF and IL-1 signaling [78,79]. PTX3 was demonstrated to form complexes with MBL or ficolin-2 to promote the deposition of complement on surfaces of $C$. albicans and A. fumigatus, respectively, resulting in their phagocytosis [80,81]. In addition, the retinoic-acid-inducible 
gene I (RIG-I) like receptor was also shown to recognize C. albicans, but its role remains unclear [82]. However, the mice deficient in the major PRRs TLR2 or dectin-1 were not susceptible to OPC, assuming these signaling pathways to be dispensable for C. albicans elimination $[83,84]$. Hence, other mechanisms involved in fungal recognition by epithelial cells seem to be more important and are discussed in further detail below.

\subsection{Recognition of C. albicans by Epithelial Cells}

In oral epithelial cells, C. albicans has been shown to interact with host epidermal growth factor receptor (EGFR) and human epidermal growth factor receptor 2 (Her2) to induce NF- $\kappa \mathrm{B}$ pathway activation, especially during the first two hours post-infection (hpi) [85,86]. Major fungal invasins Als3 and Ssa1 can interact with host RTKs, resulting in epithelial cell endocytosis of C. albicans [86]. In this process, the toxin called candidalysin plays a major role in the activation of immune response through EGFR tyrosine phosphorylation at Y-845 and Y-1068, [84,87]. Aryl hydrocarbon receptor $(\mathrm{AhR})$ was shown to mediate EGFR phosphorylation at Y-1068 via activation of Src family kinases [88]. In its turn, this results in the activation of ERK1/2, JNK and p38 proteins only 15 min post- infection, indicating early activation of epithelial cell response [85]. Notably, at 2 hpi ERK1/2 phosphorylated MAPK phosphatase (MKP1) resulting in downregulation of p38 and JNK, which prevented excessive cytokine production (in particular granulocyte colony stimulating factor (G-CSF) and granulocyte/macrophage colony stimulating factor (GM-CSF)) [85,89]. Another transcription factor activated upon C. albicans invasion was found to be a proto-oncogene c-Fos which, in contrast to JNK and p38, requires hypha formation by the pathogen $[85,90]$. Experiments with specific inhibitors revealed that in response to $C$. albicans, NF- $\kappa$ B promotes transcription of IL- $1 \alpha$, IL-6, and G-CSF, while JNK stimulates production of IL- $1 \alpha, \mathrm{IL}-1 \beta, \mathrm{G}-\mathrm{CSF}$, and to a lesser extent, IL-6. On the other hand, inhibition of the p38/c-Fos axis resulted in significant reduction of IL- $1 \alpha$, IL-1 $\beta$, IL-6, G-CSF and GM-CSF levels [85]. Therefore, c-Fos appears to be a major regulator of inflammatory response in oral epithelial cells, in particular upon C. albicans invasion and candidalysin release. Another RTK ephrin type-A receptor 2 (EphA2) has been recently shown to interact with $\beta$-glucans of yeast-phase C. albicans, which results in downstream phosphorylation of MAPK/ERK kinase 1/2 (MEK1/2), p38-mediated activation of c-Fos and signal transducer and activator of transcription 3 (STAT3) [91]. Inhibition of EphA2 signaling was observed to block C. albicans-induced EGFR phosphorylation, while inhibition of EGFR decreased EphA2 phosphorylation, suggesting that a reciprocal interaction between EphA2 and EGFR governs the endocytosis of C. albicans [91]. Furthermore, increase in fungal load (high multiplicity of infection) resulted in increased phosphorylation of EphA2 and MEK1/2 following with enhanced secretion of IL-8 and human $\beta$-defensin 2. Inhibition of EphA2 in the wild type mice dramatically reduced mRNA levels of Il17a (350-fold), Il22 (1000-fold), S100a8 (nine-fold), and Defb3 (sevenfold), assuming a major role of EphA2 in the host inflammatory response to $C$. albicans [91]. Besides, PRR mediated response to C. albicans infection has also been shown to occur in oral epithelial cells. TLR4 expression in epithelial cells required addition of polymorphonuclear leukocytes (PMLs) and increased in a time-dependent manner with 100-fold upregulation after $24 \mathrm{~h}$ [92]. C-type lectin dectin-1 was shown to induce NF- $\mathrm{kB}$ signaling in oral epithelial cells, though it had a limited role in the epithelial cell response to C. albicans [91]. Both TLR4 and dectin-1 were shown to play a modest role in IL-8 signaling, known to be important in the recruitment of PMLs such as macrophages and neutrophils.

\section{IL-17 Orchestrates Innate and Adaptive Immunity}

The IL-17 cytokine family comprises six members that participate in both acute and chronic inflammatory responses. IL-17A cytokine was discovered first, and other members of this family (IL-17B, IL-17C, IL-17D, IL-17E, and IL-17F) have been identified later based on amino acid sequence homology [93-97]. The most extensively studied cytokine of this family is IL-17A-a pro-inflammatory cytokine that plays a crucial role in host defense against bacterial and fungal infections. Apparently, IL-17 signaling is essential for host protection against C. albicans infection, particularly in the oral 
environment [30]. For instance, mice lacking the IL-17 receptor or its key downstream signaling adaptor Act1 were highly susceptible to OPC [98]. Furthermore, patients with inherited mutations in the IL-17 receptor signaling or with hyper-IgE syndrome were susceptible to chronic mucocutaneous candidiasis, signifying a role of the IL-17 immunity against $C$. albicans [99]. Potential antifungal activity of IL-17 involves regulation of the expression of antimicrobial peptides and histatins, as well as recruitment and activation of neutrophils $[100,101]$. Although, neutrophil recruitment and activity were not impaired in IL-17RA- and IL-17RC-deficient mice or in mice with depletion of IL-17A and IL-17F cytokines [102]. The major source of IL-17 is classically considered to be Th17 effector cells; however, it can also be produced by other cell types, the most prominent of which are various innate cells collectively called Type 17 cells [29]. Type 17 cells can provide quick production (within hours) of IL-17 in response to pathogens or tissue injury. This group includes certain nTh17 cells, $\gamma \delta \mathrm{T}$ cells, iNKT and an innate lymphoid cell (ILC) population known as ILC3 [31]. IL-17-secreting cells represent a small cell population in healthy oral tissues in mice and humans [30]. In healthy human gingiva Th17 cells constitute most IL-17 secreting cells, while in mice, the predominant IL-17-secreting cells are $\gamma \delta$ T cells, followed by nTh17 cells and ILC3s, though their contribution is controversial [28]. Thereby, a range of innate cells provides initial IL-17 production, which in turn orchestrates various immune events to provide protection against $C$. albicans.

\section{1. $n$ Th17 Cells}

Natural IL-17-producing T cells were first described by Marks et al. in 2009 [103]. These cells develop in the thymus and enter the bloodstream as mature cells expressing IL-23R, CD4, CCR6, $\alpha 4 \beta 1$ (VLA4, CD49d/CD29) and TCR- $\alpha \beta$ surface receptors as well as retinoic acid-related orphan receptor gamma $t$ (ROR $\gamma \mathrm{t})$ transcription factor [103-105]. nTh17 cells are intrathymically selected based on agonist stimulation by self-antigen as was shown in AND $\times$ PCC double-transgenic mice (B10.BR mice bearing the AND TCR transgene specific for a peptide of pigeon cytochrome c (PCC) crossed with mice expressing pigeon cytochrome $\mathrm{c}$ under control of an MHC class I promoter) [103]. Intact medullary epithelial compartments and MHC class II expression by thymic stroma are essential for nTh17 cells development, while expression of the autoimmune regulator (Aire), CD80/86 and ICOS-ligand co-stimulatory molecules regulates nTh17 development. Interestingly, in comparison with the reported role of the inducible nitric oxide synthase (iNOS) in the negative regulation of conventional Th17, thymic nTh17 cells do not require iNOS activity [106]. In AND $\times$ PCC double-transgenic animals, nTh17 cells were shown to mainly localize in peripheral organs including lamina propria, liver, lung and Peyer's patches [103]. However, another study indicated that nTh17 cells were abundant in lymph nodes, but not in lamina propria [107].

Even though the sequencing of the nTh17 TCR repertoire revealed a high degree of diversity, nTh17 cells possess innate-like features [31]. First, nTh17 cells, similar to innate type $\gamma \delta$ T cells, secrete IL-17 as a major proinflammatory mediator and are capable of modulating peripheral inflammatory responses. Then, same as other innate-like T cells (for instance iNKT), nTh17 cells express high levels of the transcriptional repressor promyelocytic leukemia zinc finger (PLZF). Along with PLZF protein, ROR $\gamma \mathrm{t}$ serves as a characteristic marker for the identification of nTh17 cells in the thymus and periphery [107]. Although nTh17 cells in some aspects are similar to inducible Th17 (iTh17), for instance in expression of ROR $\gamma t$ and production of IL-17 and IL-22, nTh17 are suggested to differ from peripherally induced Th17 via their innate-like ability to produce IL-17A and IL-22 after TCR-independent TLR-driven cytokine stimulation driven by TLR activation (i.e., IL-1 $\beta$ and IL-23) [31]. This was shown by the administration of imiquimod (IMQ), a TLR7 ligand, which increased the in vivo production of IL-17 in nTh17 cells. Furthermore, in IMQ-treated mice, these cells represent one of the major IL-17-producing T cell subsets present in draining lymph nodes [107]. Unlike iTh17 cells, nTh17 cells did not require IL-6 signaling for their development [105,107], although the opposite assumption was shown first [103]. Little is known about the role of nTh17 cells in infection. Nonetheless, it was demonstrated that lung epithelial cells (LEC) regulate innate antifungal immunity against Blastomyces dermatitidis by expanding the numbers 
of IL-17A- and GM-CSF-producing innate lymphocytes, particularly nTh17 cells in mice. LECs are assumed to regulate the numbers of nTh17 cells via the production of chemokines such as CCL20, whereas this process depends on IL- $1 \alpha$ signaling [108]. Conventional Th17 cells were shown to be dispensable for C. albicans elimination in the OPC model since IL-6-/- mice were capable of clearing the pathogen from the oral cavity. After 48 hpi in the oral mucosa, C. albicans increased the number of nTh17 cells in the tongue approximately twofold [31]. Conversely, nTh17 cells were not detected in tongues of C. albicans-infected Rag1-/-, IL-7R $\alpha-/-$ and in germ-free mice, suggesting that commensal microflora are needed for their development or recruitment to the oral mucosa. Remarkably, there was no expansion of nTh17 cells upon exposure to Candida glabrata, showing that different species belonging to the same genus may have distinct immune responses, possibly due to redundancy of Type 17 cells. The authors suggested that nTh17 cells mediating the innate response to OPC may explain the high susceptibility of AIDS patients to this disease, since depletion of CD4+ cells by HIV would likely affect nTh17 cells as well [31].

\section{2. $\gamma \delta T$ Cells}

$\gamma \delta \mathrm{T}$ cells are thymus-derived T cells expressing heterodimeric T-cell receptors (TCR) composed of (TCR) $\gamma /$ TCR $\delta$ chains on their cell surface [109-111]. $\gamma \delta$ T cells consist of various subsets which are localized in different anatomical locations and provide first line defense against viral, bacterial and fungal pathogens [112]. For instance, gingival $\gamma \delta \mathrm{T}$ cells of adult mice are mainly composed of $\mathrm{V} \gamma 6+(\sim 60 \%)$ and $\mathrm{V} \gamma 1+(\sim 20 \%)$, while other subsets $\mathrm{V} \gamma 4+(\sim 10 \%), \mathrm{V} \gamma 5+(\sim 5 \%)$ and $\mathrm{V} \gamma 7+(\sim 2 \%)$ are less enriched in this area [113]. They reside in the basal layer of the oral epithelium and in the junctional epithelium close to the dental biofilm, where they can reach the suprabasal layers [114]. It was demonstrated that during C. albicans infection in HIV patients the number of V $\delta 1 \mathrm{~T}$ cells was significantly higher when compared to HIV-patients with no infection. Moreover, C. albicans was shown to drive proliferation and IL-17 production by human V $\delta 1 \mathrm{~T}$ cells in vitro [115]. Although some V81 T cells can produce IL-17 upon direct contact with the fungus, a more significant amount of IL-17 production requires the DC-dependent proliferation of V $\delta 1 \mathrm{~T}$ cells [116]. IL-17 production by V $\delta 1$ T cells requires IL- $1 \beta$, IL- 6 and IL-23 secretion by DCs induced by $C$. albicans. However, addition of these cytokines in the absence of DCs was not sufficient to induce V $\delta 1 \mathrm{~T}$ cell proliferation and respective IL-17 secretion. Therefore, direct contact with DCs is required for proliferation of V $\delta 1$ $\mathrm{T}$ cells. These results suggest that $\mathrm{V} \delta 1 \mathrm{~T}$ cells are likely to be important mediators of immunity against candidiasis, particularly in the HIV infected patients which have much less CD4+ Th17 cells [116]. IL-17 expression by tongue-resident $\gamma \delta \mathrm{T}$ cells in mice is considered to be mediated by $\mathrm{V} \gamma 6$ cells, which are the main subset of $\gamma \delta \mathrm{T}$ cells in the tongue as well $[117,118]$. They play an important role in OPC in mice, although TCR- $\delta-/-$ mice are mainly resistant to oral candidiasis [31]. $\gamma \delta \mathrm{T}$ cells can produce high amounts of IL-17 on a per-cell basis [119,120], and thus are potentially an important source of oral IL-17, which plays a crucial role in OPC $[30,114]$. Interestingly, the development of uterine $\gamma \delta \mathrm{T}$ cells in mice was independent from microflora, while $\mathrm{V} \gamma 6+\gamma \delta \mathrm{T}$ cells in the gingiva were shown to be dependent $[114,121]$. Notably, this salient feature of gingival $\gamma \delta \mathrm{T}$ cells appeared to have a subset-dependency since $V \gamma 4+\gamma \delta \mathrm{T}$ cells were unaffected. Therefore, $\gamma \delta \mathrm{T}$ cells activity depends on many factors, such as host and tissue specificity, and immune environment, which implicates complex interplay between C. albicans and its host. For instance, deficiency of $V \gamma \sigma+\gamma \delta \mathrm{T}$ cells was shown to impair recruitment of neutrophils in mice reproductive tract, which severely impaired resistance to $C$. albicans [121]. Kidney-resident $\gamma \delta \mathrm{T}$ cells with a 6- to 7-fold increase were shown to be the primary source of IL-17 during disseminated C. albicans infection [122]. Upon infection with C. albicans, dermal $\gamma \delta$ T cells produce IL-17A to provide resistance to cutaneous candidiasis, and this requires IL-23 production by dermal DCs $[123,124]$. By summarizing these findings, $\gamma \delta \mathrm{T}$ cells comprise diverse subsets present in different tissues and play a vital role in IL-17 signaling. 


\section{3. $i N K T$}

iNKT cells are innate-like T lymphocytes which recognize endogenous and foreign lipid antigens presented in the nonpolymorphic MHC-I-like molecule CD1d [125,126]. iNKTs are self-reactive cells expressing a semi-invariant TCR with a canonical TCR $\alpha$ and limited set of TCRV $\beta$ chains. These cells play an important role in early immune response against different pathogens and they respond rapidly upon primary TCR stimulation by releasing large quantities of cytokines, such as interferon gamma (IFN- $\gamma$ ), TNF, IL-2, IL-3, IL-4, IL-5, IL-9, IL-10, IL-13, IL-17, IL-21, and GM-CSF [127,128]. In mice, it has been established that iNKT cells can be subdivided into three heterogeneous populations, which resemble subsets of CD4 ${ }^{+} \mathrm{T}$ cells and innate ILCs $[129,130]$. For example, iNKT1 cells are similar to Th1 T cells and ILC1s in the expression of transcription factor T-bet and secretion of IFN $\gamma$ upon activation. iNKT2 cells secrete cytokines that include IL-4 and IL-13, and therefore resemble Th2 cells, whereas iNKT17 cells are similar to Th17 cells with regard to their cytokine secretion profile. Moreover, iNKT cell subsets express different integrins, as well as cytokine receptors, which allows them to populate different tissues after completing the development in the thymus $[130,131]$. Human iNKT cells have not been studied to an equal extent as murine iNKT cells. However, it was demonstrated that double-negative iNKT cells $\left(\mathrm{CD} 4^{-}\right.$and $\left.\mathrm{CD} 8^{-}\right)$in human blood and those that express CD8 (either $\mathrm{CD} 8 \alpha \alpha$ or $\mathrm{CD} 8 \alpha \beta)$ are different from $\mathrm{CD}^{+}{ }^{+}$iNKT cells $[127,132]$. The double-negative and $\mathrm{CD} 8^{+}$ iNKT cells found in humans were described to resemble mouse iNKT1 cells, showing increased IFN $\gamma$ secretion and cytotoxic function when activated [127,133]. Recently Erkers et al. suggested that iNKT cells are better described as T-cell-like and NK-like [134]. Killer cell lectin-like receptor subfamily G member 1 (KLRG1) and CD94 markers were used to define iNKT subsets. KLRG1 was expressed in both $\mathrm{CD} 4^{+}$and $\mathrm{CD} 4^{-}$cells and was associated with the production of Th1 cytokines, while $\mathrm{CD} 4^{+}$cells were also able to produce IL-4. CD94 was expressed only by CD4 ${ }^{-}$cells which did not express any IL-4 and displayed elevated cytotoxicity. In addition, human iNKT cells have also been recorded as capable of producing IL-17 in a pro-inflammatory environment [134].

Little is known about the role of iNKT cells in fungal infections. iNKT cells have been shown to be activated by the fungus Aspergillus fumigatus both in vitro in the presence of antigen-presenting cells and in vivo after fungal infection [135]. Furthermore, CD1d-/- mice were impaired in their ability to rapidly control A. fumigatus infection. Interestingly, similar to A. fumigatus, Histoplasma capsulatum and Alternaria alternata, C. albicans activates iNKT cells via fungal $\beta 1,3$-glucan recognition by Dectin-1 and subsequent IL-12 secretion by activated CD1d-expressing antigen-presenting cells in vitro [135]. In another study, it was shown that cholesteryl $6^{\prime}$-O-acyl $\alpha$-mannoside, found in C. albicans induced activation of mouse and human iNKT cells, dependent on CD1d [136]. However, intravenous C. albicans infection of J alpha $18 \mathrm{KO}$ mice which specifically lack iNKT cells, has shown that iNKT cells play a minor role in controlling systemic C. albicans infections since survival, fungal burden, and production of inflammatory cytokines in several organs did not significantly change during infection [137]. In addition, CD1d-/- mice have also exhibited resistance to oral candidiasis, confirming the marginal role of iNKT cells in C. albicans infection [31].

\subsection{ILC3}

ILCs resemble $\mathrm{T}$ lymphocytes, but lack adaptive antigen receptors generated by the VDJ recombination. ILC1s, ILC2s and ILC3s are functionally similar to CD4+ T helper cell subsets Th1, Th2 and Th17 cells, respectively $[138,139]$. Since ILC3 shares functional similarities with the Th17 subset, it was suggested that ILC3 can be a source of IL-17A during the early stages of OPC, which was confirmed in experimentally infected mice [140]. However, another group reported that IL-17 is primarily expressed during OPC by nTh17 and $\gamma \delta$ T cells, but not by ILCs [31]. Perhaps the conflicting results were due to the indirect measurements of IL-17A (Il17a and Il17f transcripts in crude tongue extracts or IL-17A promoter activity in Il17a-eYFP fate reporter mice) production during infection [140]. Interestingly, eYFP-expressing ILC3 cells were not detected in both C. albicans-infected and sham kidneys [122]. However, later it was demonstrated by direct visualization of IL-17A and 
IL-17F cytokines in the infected tongue that three separate and complementary IL-17-producing cell types exist, namely nTh17s, $\gamma \delta$ T cells and ILC3s [141]. Thus, these three subsets can compensate for each other's function. For instance, lack of nTh17 or $\gamma \delta$ T cells does not affect fungal control and only deletion of all three subsets resembles the high susceptibility of IL-17RA or IL-17RC-deficient mice to OPC, underlining the robustness of the IL-17 response to the fungus [24].

\section{Outlook and Perspectives}

Persisting C. albicans cells challenge oral tissue by stimulation of host intracellular signaling, which in response aims to eradicate exogenous pathogens. Activated transcription factors provide initial recruitment of innate cells, including nTh17, $\gamma \delta \mathrm{T}$ cells, iNKTs and ILC3 cells, aimed to produce IL-17. This important cytokine in OPC initiates and multiplies neutrophil-mediated fungi elimination. However, the role of type 17 cells is still not clear in response to human OPC since the main protection is provided via conventional Th17 cells. These cells may play an important role in protection against $C$. albicans in individuals with $\mathrm{CD}^{+} \mathrm{T}$ cell deficiency, for instance in HIV-positive patients. Therefore, better understanding of biology of IL-17 producing cells and their role in human candidiasis may help to develop new approaches for treatment methods. In addition, increased prostaglandin levels during fungal infections can exacerbate fungal colonization and trigger chronic infection [58]. Thus, different enzymes of arachidonic acid pathways, for instance CPLA2 $\alpha$, can serve as a target for the development of new therapeutic strategies against C. albicans [62]. Altogether, this may constitute the object of future studies.

In addition, C. albicans can escape from the host's defense mechanisms in multiple ways. Besides genetically determined resistance, $C$. albicans can form rigid biofilms where cells become phenotypically resistant to antimicrobials and the immune system [142-145]. It appears that we still have a long way to go to understand how the immune system overcomes biofilm-associated resistance. Nevertheless, many studies have already resolved the problem in the context of pathogen recognition. RTK signaling is widely used by microbial pathogens to invade epithelial host cells and hijack their signaling for their own benefits [146,147]. Diverse pathogens such as viruses, bacteria, fungi and protozoa share similar signaling pathways to initiate host cell entry, and RTKs play a central role to initiate this process [147-151]. In this respect many efforts have been made to define Her2, EGFR and EphA2 as growth factor receptors involved in C. albicans internalization [86,87,91]. For instance, dysregulation of EGFR in gastric epithelial cells by another pathogen Helicobacter pylori has been shown to lead to gastric disorders, such as peptic ulceration and neoplastic transformation [152-154]. Association of $C$. albicans with cancer progression is less established; however, analysis of nationwide medical registries in Denmark and Taiwan have reported increased cancer risks upon C. albicans infection [155-158]. Inflammation triggered by C. albicans, in particular IL-17-driven, indeed may contribute to the tumorigenesis, as it has been shown for autoimmune disorders [159-162]. However, the role for innate and adaptive arms of immunity in C. albicans-driven tumorigenesis remains widely obscured and further research could elucidate this important question.

Author Contributions: A.P. and I.S. equally contributed to this work. All authors have read and agreed to the published version of the manuscript.

Funding: We thank Friedrich-Alexander-Universität Erlangen-Nürnberg (FAU) within the funding program Open Access Publishing.

Conflicts of Interest: The authors declare no conflict of interest. The funders had no role in the design of the study; in the collection, analyses, or interpretation of data; in the writing of the manuscript; or in the decision to publish the results. 


\section{References}

1. Oever, J.T.; Netea, M.G. The bacteriome-mycobiome interaction and antifungal host defense. Eur. J. Immunol. 2014, 44, 3182-3191. [CrossRef] [PubMed]

2. Bertolini, M.; Ranjan, A.; Thompson, A.; Diaz, P.I.; Sobue, T.; Maas, K.; Dongari-Bagtzoglou, A. Candida albicans induces mucosal bacterial dysbiosis that promotes invasive infection. PLoS Pathog. 2019, 15, e1007717. [CrossRef] [PubMed]

3. Bartnicka, D.; Gonzalez-Gonzalez, M.; Sykut, J.; Koziel, J.; Ciaston, I.; Adamowicz, K.; Bras, G.; Zawrotniak, M.; Karkowska-Kuleta, J.; Satala, D.; et al. Candida albicans Shields the Periodontal Killer Porphyromonas gingivalis from Recognition by the Host Immune System and Supports the Bacterial Infection of Gingival Tissue. Int. J. Mol. Sci. 2020, 21, 1984. [CrossRef] [PubMed]

4. Passariello, C.; di Nardo, F.; Polimeni, A.; di Nardo, D.; Testarelli, L. Probiotic Streptococcus salivarius Reduces Symptoms of Denture Stomatitis and Oral Colonization by Candida albicans. Appl. Sci. 2020, 10, 3002. [CrossRef]

5. Marol, S.; Yuecesoy, M. Molecular epidemiology of Candida species isolated from clinical specimens of intensive care unit patients. Mycoses 2008, 51, 40-49. [CrossRef]

6. Eggimann, P.; Garbino, J.; Pittet, D. Epidemiology of Candida species infections in critically ill non-immunosuppressed patients. Lancet Infect. Dis. 2003, 3, 685-702. [CrossRef]

7. Gow, N.A.R.; Yadav, B. Microbe Profile: Candida albicans: A shape-changing, opportunistic pathogenic fungus of humans. Microbiol. SGM 2017, 163, 1145-1147. [CrossRef]

8. Southern, P.; Horbul, J.; Maher, D.; Davis, D.A. C. albicans Colonization of Human Mucosal Surfaces. PLoS ONE 2008, 3, e2067. [CrossRef]

9. Tsui, C.; Kong, E.F.; Jabra-Rizk, M.A. Pathogenesis of Candida albicans biofilm. Pathog. Dis. 2016, 74, ftw018. [CrossRef]

10. Mukaremera, L.; Lee, K.K.; Mora-Montes, H.M.; Gow, N.A.R. Candida albicans Yeast, Pseudohyphal, and hyphal Morphogenesis Differentially affects immune recognition. Front. Immunol. 2017, 8, 629. [CrossRef]

11. Boxx, G.M.; Kozel, T.R.; Nishiya, C.T.; Zhang, M.X. Influence of Mannan and Glucan on Complement Activation and C3 Binding by Candida albicans. Infect. Immun. 2010, 78, 1250-1259. [CrossRef] [PubMed]

12. Bain, J.M.; Louw, J.; Lewis, L.E.; Okai, B.; Walls, C.A.; Ballou, E.R.; Walker, L.A.; Reid, D.; Munro, C.A.; Brown, A.J.P.; et al. Candida albicans Hypha Formation and Mannan Masking of beta-Glucan Inhibit Macrophage Phagosome Maturation. Mbio 2014, 5, e01874. [CrossRef]

13. Hofs, S.; Mogavero, S.; Hube, B. Interaction of Candida albicans with host cells: Virulence factors, host defense, escape strategies, and the microbiota. J. Microbiol. 2016, 54, 149-169. [CrossRef] [PubMed]

14. Bodey, G.P.; Mardani, M.; Hanna, H.A.; Boktour, M.; Abbas, J.; Girgawy, E.; Hachem, R.Y.; Kontoyiannis, D.P.; Raad, I.I. The epidemiology of Candida glabrata and Candida albicans fungemia in immunocompromised patients with cancer. Am. J. Med. 2002, 112, 380-385. [CrossRef]

15. Vallabhaneni, S.; Mody, R.K.; Walker, T.; Chiller, T. The Global Burden of Fungal Diseases. Infect. Dis. Clin. N. Am. 2016, 30, 1-11. [CrossRef]

16. Ghannoum, M.A.; Jurevic, R.J.; Mukherjee, P.K.; Cui, F.; Sikaroodi, M.; Naqvi, A.; Gillevet, P.M. Characterization of the Oral Fungal Microbiome (Mycobiome) in Healthy Individuals. PLoS Pathog. 2010, 6, e1000713. [CrossRef]

17. Dupuy, A.K.; David, M.S.; Li, L.; Heider, T.N.; Peterson, J.D.; Montano, E.A.; Dongari-Bagtzoglou, A.; Diaz, P.I.; Strausbaugh, L.D. Redefining the Human Oral Mycobiome with Improved Practices in Amplicon-based Taxonomy: Discovery of Malassezia as a Prominent Commensal. PLoS ONE 2014, 9, e90899. [CrossRef]

18. Metwalli, K.H.; Khan, S.A.; Krom, B.P.; Jabra-Rizk, M.A. Streptococcus mutans, Candida albicans, and the Human Mouth: A Sticky Situation. PLoS Pathog. 2013, 9, e1003616. [CrossRef]

19. Patton, L.L. Progress in understanding oral health and HIV/AIDS. Oral Dis. 2014, 20, 223-225. [CrossRef]

20. Patil, S.; Majumdar, B.; Sarode, S.C.; Sarode, G.S.; Awan, K.H. Oropharyngeal Candidosis in HIV-Infected Patients-An Update. Front. Microbiol. 2018, 9, 980. [CrossRef]

21. UNAIDS. UNAIDS (Joint United Nations Programme on HIV/AIDS) Data 2019; UNAIDS: Geneva, Switzerland, 2019.

22. Van de Veerdonk, F.L.; Kullberg, B.J.; Netea, M.G. Pathogenesis of invasive candidiasis. Curr. Opin. Crit. Care 2010, 16, 453-459. [CrossRef] [PubMed] 
23. Hebecker, B.; Naglik, J.R.; Hube, B.; Jacobsen, I.D. Pathogenicity mechanisms and host response during oral Candida albicans infections. Expert Rev. Anti Infect. Ther. 2014, 12, 867-879. [CrossRef] [PubMed]

24. Conti, H.R.; Shen, F.; Nayyar, N.; Stocum, E.; Sun, J.N.; Lindemann, M.J.; Ho, A.W.; Hai, J.H.; Yu, J.J.; Jung, J.W.; et al. Th17 cells and IL-17 receptor signaling are essential for mucosal host defense against oral candidiasis. J. Exp. Med. 2009, 206, 299-311. [CrossRef] [PubMed]

25. Cheng, S.C.; Joosten, L.A.B.; Kullberg, B.J.; Netea, M.G. Interplay between Candida albicans and the Mammalian Innate Host Defense. Infect. Immun. 2012, 80, 1304-1313. [CrossRef]

26. Byrd, A.S.; O’Brien, X.M.; Johnson, C.M.; Lavigne, L.M.; Reichner, J.S. An Extracellular Matrix-Based Mechanism of Rapid Neutrophil Extracellular Trap Formation in Response to Candida albicans. J. Immunol. 2013, 190, 4136-4148. [CrossRef]

27. Urban, C.F.; Ermert, D.; Schmid, M.; Abu-Abed, U.; Goosmann, C.; Nacken, W.; Brinkmann, V.; Jungblut, P.R.; Zychlinsky, A. Neutrophil Extracellular Traps Contain Calprotectin, a Cytosolic Protein Complex Involved in Host Defense against Candida albicans. PLoS Pathog. 2009, 5, e1000639. [CrossRef]

28. Dutzan, N.; Kajikawa, T.; Abusleme, L.; Greenwell-Wild, T.; Zuazo, C.E.; Ikeuchi, T.; Brenchley, L.; Abe, T.; Hurabielle, C.; Martin, D.; et al. A dysbiotic microbiome triggers $\mathrm{T}(\mathrm{H}) 17$ cells to mediate oral mucosal immunopathology in mice and humans. Sci. Transl. Med. 2018, 10, eaat0797. [CrossRef]

29. Cua, D.J.; Tato, C.M. Innate IL-17-producing cells: The sentinels of the immune system. Nat. Rev. Immunol. 2010, 10, 479-489. [CrossRef]

30. Gaffen, S.L.; Moutsopoulos, N.M. Regulation of host-microbe interactions at oral mucosal barriers by type 17 immunity. Sci. Immunol. 2020, 5, eaau4594. [CrossRef]

31. Conti, H.R.; Peterson, A.C.; Brane, L.; Huppler, A.R.; Hernandez-Santos, N.; Whibley, N.; Garg, A.V.; Simpson-Abelson, M.R.; Gibson, G.A.; Mamo, A.J.; et al. Oral-resident natural Th17 cells and gamma delta T cells control opportunistic Candida albicans infections. J. Exp. Med. 2014, 211, 2075-2084. [CrossRef]

32. Rosati, D.; Bruno, M.; Jaeger, M.; Oever, J.T.; Netea, M.G. Recurrent Vulvovaginal Candidiasis: An Immunological Perspective. Microorganisms 2020, 8, 144. [CrossRef] [PubMed]

33. Mengesha, B.G.; Conti, H.R. The Role of IL-17 in Protection against Mucosal Candida Infections. J. Fungi 2017, 3, 52. [CrossRef]

34. Peters, B.M.; Coleman, B.M.; Willems, H.M.E.; Barker, K.S.; Aggor, F.E.Y.; Cipolla, E.; Verma, A.H.; Bishu, S.; Huppler, A.H.; Bruno, V.M.; et al. The Interleukin (IL) 17R/IL-22R Signaling Axis Is Dispensable for Vulvovaginal Candidiasis Regardless of Estrogen Status. J. Infect. Dis. 2020, 221, 1554-1563. [CrossRef] [PubMed]

35. Gow, N.A.R.; Hube, B. Importance of the Candida albicans cell wall during commensalism and infection. Curr. Opin. Microbiol. 2012, 15, 406-412. [CrossRef] [PubMed]

36. Brown, G.D.; Gordon, S. Immune recognition of fungal beta-glucans. Cell. Microbiol. 2005, 7, 471-479. [CrossRef]

37. Gow, N.A.R.; Latge, J.P.; Munro, C.A. The Fungal Cell Wall: Structure, Biosynthesis, and Function. Microbiol. Spectr. 2017, 5. [CrossRef]

38. Swidergall, M. Candida albicans at Host Barrier Sites: Pattern Recognition Receptors and Beyond. Pathogens 2019, 8, 40. [CrossRef]

39. Pinheiro, C.R.; Coelho, A.L.; de Oliveira, C.E.; Gasparoto, T.H.; Garlet, G.P.; Silva, J.S.; Santos, C.F.; Cavassani, K.A.; Hogaboam, C.M.; Campanelli, A.P. Recognition of Candida albicans by gingival fibroblasts: The role of TLR2, TLR4/CD14, and MyD88. Cytokine 2018, 106, 67-75. [CrossRef]

40. Netea, M.G.; Brown, G.D.; Kullberg, B.J.; Gow, N.A.R. An integrated model of the recognition of Candida albicans by the innate immune system. Nat. Rev. Microbiol. 2008, 6, 67-78. [CrossRef]

41. Swidergall, M.; Ernst, J.F. Interplay between Candida albicans and the Antimicrobial Peptide Armory. Eukaryot. Cell 2014, 13, 950-957. [CrossRef]

42. Taylor, P.R.; Tsoni, S.V.; Willment, J.A.; Dennehy, K.M.; Rosas, M.; Findon, H.; Haynes, K.; Steele, C.; Botto, M.; Gordon, S.; et al. Dectin-1 is required for beta-glucan recognition and control of fungal infection. Nat. Immunol. 2007, 8, 31-38. [CrossRef]

43. Zhu, L.L.; Zhao, X.Q.; Jiang, C.Y.; You, Y.; Chen, X.P.; Jiang, Y.Y.; Jia, X.M.; Lin, X. C-Type Lectin Receptors Dectin-3 and Dectin-2 Form a Heterodimeric Pattern-Recognition Receptor for Host Defense against Fungal Infection. Immunity 2013, 39, 324-334. [CrossRef] [PubMed] 
44. Brown, G.D.; Taylor, P.R.; Reid, D.M.; Willment, J.A.; Williams, D.L.; Martinez-Pomares, L.; Wong, S.Y.C.; Gordon, S. Dectin-1 is a major beta-glucan receptor on macrophages. J. Exp. Med. 2002, 196, 407-412. [CrossRef] [PubMed]

45. Saijo, S.; Ikeda, S.; Yamabe, K.; Kakuta, S.; Ishigame, H.; Akitsu, A.; Fujikado, N.; Kusaka, T.; Kubo, S.; Chung, S.H.; et al. Dectin-2 Recognition of alpha-Mannans and Induction of Th17 Cell Differentiation Is Essential for Host Defense against Candida albicans. Immunity 2010, 32, 681-691. [CrossRef] [PubMed]

46. Osorio, F.; Sousa, G.R.E. Myeloid C-type Lectin Receptors in Pathogen Recognition and Host Defense. Immunity 2011, 34, 651-664. [CrossRef] [PubMed]

47. Robinson, M.J.; Osorio, F.; Rosas, M.; Freitas, R.P.; Schweighoffer, E.; Gross, O.; SjefVerbeek, J.; Ruland, J.; Tybulewicz, V.; Brown, G.D.; et al. Dectin-2 is a Syk-coupled pattern recognition receptor crucial for Th17 responses to fungal infection. J. Exp. Med. 2009, 206, 2037-2051. [CrossRef] [PubMed]

48. Gross, O.; Gewies, A.; Finger, K.; Schafer, M.; Sparwasser, T.; Peschel, C.; Forster, I.; Ruland, J. Card9 controls a non-TLR signalling pathway for innate anti-fungal immunity. Nature 2006, 442, 651-656. [CrossRef]

49. Slack, E.C.; Robinson, M.J.; Hernanz-Falcon, P.; Brown, G.D.; Williams, D.L.; Schweighoffer, E.; Tybulewicz, V.L.; Sousa, C.R.E. Syk-dependent ERK activation regulates IL-2 and IL-10 production by DC stimulated with zymosan. Eur. J. Immunol. 2007, 37, 1600-1612. [CrossRef]

50. Goodridge, H.S.; Simmons, R.M.; Underhill, D.M. Dectin-1 stimulation by Candida albicans yeast or zymosan triggers NFAT activation in macrophages and dendritic cells. J. Immunol. 2007, 178, 3107-3115. [CrossRef]

51. Sancho, D.; Sousa, C.R.E. Signaling by Myeloid C-Type Lectin Receptors in Immunity and Homeostasis. Annu. Rev. Immunol. 2012, 30, 491-529. [CrossRef]

52. Carvalho, A.; Giovannini, G.; de Luca, A.; D’Angelo, C.; Casagrande, A.; Iannitti, R.G.; Ricci, G.; Cunha, C.; Romani, L. Dectin-1 isoforms contribute to distinct Th1/Th17 cell activation in mucosal candidiasis. Cell. Mol. Immunol. 2012, 9, 276-286. [CrossRef] [PubMed]

53. Hohl, T.M.; van Epps, H.L.; Rivera, A.; Morgan, L.A.; Chen, P.L.; Feldmesser, M.; Pamer, E.G. Aspergillus fumigatus triggers inflammatory responses by stage-specific beta-glucan display. PLoS Pathog. 2005, 1, 232-240. [CrossRef]

54. Suram, S.; Brown, G.D.; Ghosh, M.; Gordon, S.; Loper, R.; Taylor, P.R.; Akira, S.; Uematsu, S.; Williams, D.L.; Leslie, C.C. Regulation of cytosolic phospholipase A(2) activation and cyclooxygenase 2 expression in macrophages by the beta-glucan receptor. J. Biol. Chem. 2006, 281, 5506-5514. [CrossRef] [PubMed]

55. Suram, S.; Gangelhoff, T.A.; Taylor, P.R.; Rosas, M.; Brown, G.D.; Bonventre, J.V.; Akira, S.; Uematsu, S.; Williams, D.L.; Murphy, R.C.; et al. Pathways Regulating Cytosolic Phospholipase A(2) Activation and Eicosanoid Production in Macrophages by Candida albicans. J. Biol. Chem. 2010, 285, 30676-30685. [CrossRef] [PubMed]

56. Harris, S.G.; Padilla, J.; Koumas, L.; Ray, D.; Phipps, R.P. Prostaglandins as modulators of immunity. Trends Immunol. 2002, 23, 144-150. [CrossRef]

57. Aoki, T.; Narumiya, S. Prostaglandins and chronic inflammation. Trends Pharmcol. Sci. 2012, 33, $304-311$. [CrossRef]

58. Noverr, M.C.; Phare, S.M.; Toews, G.B.; Coffey, M.J.; Huffnagle, G.B. Pathogenic yeasts Cryptococcus neoformans and Candida albicans produce immunomodulatory prostaglandins. Infect. Immun. 2001, 69, 2957-2963. [CrossRef]

59. Tan, T.G.; Lim, Y.S.; Tan, A.; Leong, R.; Pavelka, N. Fungal Symbionts Produce Prostaglandin E-2 to Promote Their Intestinal Colonization. Front. Cell. Infect. Microbiol. 2019, 9, 359. [CrossRef]

60. Marquez, S.; Fernandez, J.J.; Mancebo, C.; Herrero-Sanchez, C.; Alonso, S.; Sandoval, T.A.; Prados, M.R.; Cubillos-Ruiz, J.R.; Montero, O.; Fernandez, N.; et al. Tricarboxylic Acid Cycle Activity and Remodeling of Glycerophosphocholine Lipids Support Cytokine Induction in Response to Fungal Patterns. Cell Rep. 2019, 27, 525. [CrossRef]

61. Strassmann, G.; Patilkoota, V.; Finkelman, F.; Fong, M.; Kambayashi, T. Evidence for the involvement of interleukin-10 in the differential deactivation of murine peritoneal-macrophages by prostaglandin-e(2). J. Exp. Med. 1994, 180, 2365-2370. [CrossRef]

62. Liu, X.N.; Wang, D.; Yu, C.X.; Li, T.; Liu, J.Q.; Sun, S.J. Potential Antifungal Targets against a Candida Biofilm Based on an Enzyme in the Arachidonic Acid Cascade-A Review. Front. Microbiol. 2016, 7, 1925. [CrossRef]

63. Netea, M.G.; Joosten, L.A.B.; van der Meer, J.W.M.; Kullberg, B.J.; van de Veerdonk, F.L. Immune defence against Candida fungal infections. Nat. Rev. Immunol. 2015, 15, 630-642. [CrossRef] [PubMed] 
64. Roeder, A.; Kirschning, C.J.; Schaller, M.; Weindl, G.; Wagner, H.; Korting, H.C.; Rupec, R.A. Induction of nuclear factor-kappa B and c-Jun/activator protein-1 via Toll-like receptor 2 in macrophages by antimycotic-treated Candida albicans. J. Infect. Dis. 2004, 190, 1318-1326. [CrossRef] [PubMed]

65. Murciano, C.; Yanez, A.; Gil, M.L.; Gozalbo, D. Both viable and killed Candida albicans cells induce in vitro production of TNF-alpha and IFN-gamma in murine cells through a TLR2-dependent signalling. Eur. Cytokine Netw. 2007, 18, 38-43. [PubMed]

66. Archambault, L.S.; Trzilova, D.; Gonia, S.; Gale, C.; Wheeler, R.T. Intravital Imaging Reveals Divergent Cytokine and Cellular Immune Responses to Candida albicans and Candida parapsilosis. Mbio 2019, 10, e00266-19. [CrossRef]

67. Gil, M.L.; Gozalbo, D. TLR2, but not TLR4, triggers cytokine production by murine cells in response to Candida albicans yeasts and hyphae. Microbes Infect. 2006, 8, 2299-2304. [CrossRef]

68. Netea, M.G.; van der Meer, J.W.M.; Kullberg, B.J. Both TLR2 and TLR4 are involved in the recognition of Candida albicans. Reply to "TLR2, but not TLR4, triggers cytokine production by murine cells in response to Candida albicans yeasts and hyphae" by Gil and Gozalbo, Microbes and Infection. Microbes Infect. 2006, 8, 2821-2822. [CrossRef]

69. Wang, W.J.; Deng, Z.H.; Wu, H.Y.; Zhao, Q.; Li, T.T.; Zhu, W.C.; Wang, X.J.; Tang, L.H.; Wang, C.S.; Cui, S.Z.; et al. A small secreted protein triggers a TLR2/4-dependent inflammatory response during invasive Candida albicans infection. Nat. Commun. 2019, 10, e00266-19. [CrossRef]

70. Blasi, E.; Mucci, A.; Neglia, R.; Pezzini, F.; Colombari, B.; Radzioch, D.; Cossarizza, A.; Lugli, E.; Volpini, G.; Del Giudice, G.; et al. Biological importance of the two Toll-like receptors, TLR2 and TLR4, in macrophage response to infection with Candida albicans. Fems. Immunol. Med. Microbiol. 2005, 44, 69-79. [CrossRef]

71. Hise, A.G.; Tomalka, J.; Ganesan, S.; Patel, K.; Hall, B.A.; Brown, G.D.; Fitzgerald, K.A. An Essential Role for the NLRP3 Inflammasome in Host Defense against the Human Fungal Pathogen Candida albicans. Cell Host Microbe 2009, 5, 487-497. [CrossRef]

72. Gross, O.; Poeck, H.; Bscheider, M.; Dostert, C.; Hannesschlager, N.; Endres, S.; Hartmann, G.; Tardivel, A.; Schweighoffer, E.; Tybulewicz, V.; et al. Syk kinase signalling couples to the Nlrp3 inflammasome for anti-fungal host defence. Nature 2009, 459, 433-436. [CrossRef] [PubMed]

73. Rogiers, O.; Frising, U.C.; Kucharikova, S.; Jabra-Rizk, M.A.; van Loo, G.; van Dijck, P.; Wullaert, A. Candidalysin Crucially Contributes to Nlrp3 Inflammasome Activation by Candida albicans Hyphae. Mbio 2019, 10, e02221. [CrossRef] [PubMed]

74. Kasper, L.; Konig, A.; Koenig, P.A.; Gresnigt, M.S.; Westman, J.; Drummond, R.A.; Lionakis, M.S.; Gross, O.; Ruland, J.; Naglik, J.R.; et al. The fungal peptide toxin Candidalysin activates the NLRP3 inflammasome and causes cytolysis in mononuclear phagocytes. Nat. Commun. 2018, 9, 4260. [CrossRef] [PubMed]

75. Foo, S.S.; Reading, P.C.; Jaillon, S.; Mantovani, A.; Mahalingam, S. Pentraxins and Collectins: Friend or Foe during Pathogen Invasion? Trends Microbiol. 2015, 23, 799-811. [CrossRef] [PubMed]

76. Harpf, V.; Rambach, G.; Wurzner, R.; Lass-Florl, C.; Speth, C. Candida and Complement: New Aspects in an Old Battle. Front. Immunol. 2020, 11, 1471. [CrossRef]

77. Herrero-Sanchez, M.C.; Angomas, E.B.; de Ramon, C.; Telleria, J.J.; Corchete, L.A.; Alonso, S.; Ramos, M.D.; Penarrubia, M.J.; Marquez, S.; Fernandez, N.; et al. Polymorphisms in Receptors Involved in Opsonic and Nonopsonic Phagocytosis, and Correlation with Risk of Infection in Oncohematology Patients. Infect. Immun. 2018, 86, e00709-18. [CrossRef]

78. Lee, G.W.; Lee, T.H.; Vilcek, J. TSG-14, A tumor necrosis factor-inducible and il-1-inducible protein, is a novel member of the pentaxin family of acute phase proteins. J. Immunol. 1993, 150, 1804-1812.

79. Alles, V.V.; Bottazzi, B.; Peri, G.; Golay, J.; Introna, M.; Mantovani, A. Inducible expression of ptx3, a new member of the pentraxin family, in human mononuclear phagocytes. Blood 1994, 84, 3483-3493. [CrossRef]

80. Ma, Y.J.; Doni, A.; Skjoedt, M.O.; Honore, C.; Arendrup, M.; Mantovani, A.; Garred, P. Heterocomplexes of Mannose-binding Lectin and the Pentraxins PTX3 or Serum Amyloid P Component Trigger Cross-activation of the Complement System. J. Biol. Chem. 2011, 286, 3405-3417. [CrossRef]

81. Ma, Y.J.; Doni, A.; Hummelshoj, T.; Honore, C.; Bastone, A.; Mantovani, A.; Thielens, N.M.; Garred, P. Synergy between Ficolin-2 and Pentraxin 3 Boosts Innate Immune Recognition and Complement Deposition. J. Biol. Chem. 2009, 284, 28263-28275. [CrossRef] 
82. Jaeger, M.; van der Lee, R.; Cheng, S.C.; Johnson, M.D.; Kumar, V.; Ng, A.; Plantinga, T.S.; Smeekens, S.P.; Oosting, M.; Wang, X.; et al. The RIG-I-like helicase receptor MDA5 (IFIH1) is involved in the host defense against Candida infections. Eur. J. Clin. Microbiol. Infect. Dis. 2015, 34, 963-974. [CrossRef] [PubMed]

83. Bishu, S.; Hernandez-Santos, N.; Simpson-Abelson, M.R.; Huppler, A.R.; Conti, H.R.; Ghilardi, N.; Mamo, A.J.; Gaffen, S.L. The Adaptor CARD9 Is Required for Adaptive but Not Innate Immunity to Oral Mucosal Candida albicans Infections. Infect. Immun. 2014, 82, 1173-1180. [CrossRef] [PubMed]

84. Verma, A.H.; Richardson, J.P.; Zhou, C.S.; Coleman, B.M.; Moyes, D.L.; Ho, J.; Huppler, A.R.; Ramani, K.; McGeachy, M.J.; Mufazalov, I.A.; et al. Oral epithelial cells orchestrate innate type 17 responses to Candida albicans through the virulence factor candidalysin. Sci. Immunol. 2017, 2, eaam8834. [CrossRef] [PubMed]

85. Moyes, D.L.; Runglall, M.; Murciano, C.; Shen, C.G.; Nayar, D.; Thavaraj, S.; Kohli, A.; Islam, A.; Mora-Montes, H.; Challacombe, S.J.; et al. A Biphasic Innate Immune MAPK Response Discriminates between the Yeast and Hyphal Forms of Candida albicans in Epithelial Cells. Cell Host Microbe 2010, 8, 225-235. [CrossRef]

86. Zhu, W.D.; Phan, Q.T.; Boontheung, P.; Solis, N.V.; Loo, J.A.; Filler, S.G. EGFR and HER2 receptor kinase signaling mediate epithelial cell invasion by Candida albicans during oropharyngeal infection. Proc. Natl. Acad. Sci. USA 2012, 109, 14194-14199. [CrossRef]

87. Moyes, D.L.; Wilson, D.; Richardson, J.P.; Mogavero, S.; Tang, S.X.; Wernecke, J.; Hofs, S.; Gratacap, R.L.; Robbins, J.; Runglall, M.; et al. Candidalysin is a fungal peptide toxin critical for mucosal infection. Nature 2016, 532, 64. [CrossRef]

88. Solis, N.V.; Swidergall, M.; Bruno, V.M.; Gaffen, S.L.; Filler, S.G. The Aryl Hydrocarbon Receptor Governs Epithelial Cell Invasion during Oropharyngeal Candidiasis. Mbio 2017, 8, e00025-17. [CrossRef]

89. Boutros, T.; Nantel, A.; Emadali, A.; Tzimas, G.; Conzen, S.; Chevet, E.; Metrakos, P.P. The MAP Kinase Phosphatase-1 MKP-1/DUSP1 Is a Regulator of Human Liver Response to Transplantation. Am. J. Transplant. 2008, 8, 2558-2568. [CrossRef] [PubMed]

90. Verma, A.H.; Zafar, H.; Ponde, N.O.; Hepworth, O.W.; Sihra, D.; Aggor, F.E.Y.; Ainscough, J.S.; Ho, J.; Richardson, J.P.; Coleman, B.M.; et al. IL-36 and IL-1/IL-17 Drive Immunity to Oral Candidiasis via Parallel Mechanisms. J. Immunol. 2018, 201, 627-634. [CrossRef]

91. Swidergall, M.; Solis, N.V.; Lionakis, M.S.; Filler, S.G. EphA2 is an epithelial cell pattern recognition receptor for fungal beta-glucans. Nat. Microbiol. 2018, 3, 53-61. [CrossRef]

92. Weindl, G.; Naglik, J.R.; Kaesler, S.; Biedermann, T.; Hube, B.; Korting, H.C.; Schaller, M. Human epithelial cells establish direct antifungal defense through TLR4-mediated signaling. J. Clin. Investig. 2007, 117, 3664-3672. [CrossRef] [PubMed]

93. Li, H.Z.; Chen, J.; Huang, A.; Stinson, J.; Heldens, S.; Foster, J.; Dowd, P.; Gurney, A.L.; Wood, W.I. Cloning and characterization of IL-17B and IL-17C, two new members of the IL-17 cytokine family. Proc. Natl. Acad. Sci. USA 2000, 97, 773-778. [CrossRef] [PubMed]

94. Starnes, T.; Broxmeyer, H.E.; Robertson, M.J.; Hromas, R. Cutting edge: IL-17D, a novel member of the IL-17 family, stimulates cytokine production and inhibits hemopoiesis. J. Immunol. 2002, 169, 642-646. [CrossRef] [PubMed]

95. Yoo, Z.B.; Painter, S.L.; Fanslow, W.C.; Ulrich, D.; Macduff, B.M.; Spriggs, M.K.; Armitage, R.J. Human IL-17-A novel cytokine derived from t-cells. J. Immunol. 1995, 155, 5483-5486.

96. Lee, J.; Ho, W.H.; Maruoka, M.; Corpuz, R.T.; Baldwin, D.T.; Foster, J.S.; Goddard, A.D.; Yansura, D.G.; Vandlen, R.L.; Wood, W.I.; et al. IL-17E, a novel proinflammatory ligand for the IL-17 receptor homolog IL-17Rh1. J. Biol. Chem. 2001, 276, 1660-1664. [CrossRef]

97. Hymowitz, S.G.; Filvaroff, E.H.; Yin, J.P.; Lee, J.; Cai, L.P.; Risser, P.; Maruoka, M.; Mao, W.G.; Foster, J.; Kelley, R.F.; et al. IL-17s adopt a cystine knot fold: Structure and activity of a novel cytokine, IL-17F, and implications for receptor binding. EMBO J. 2001, 20, 5332-5341. [CrossRef]

98. Ferreira, M.C.; Whibley, N.; Mamo, A.J.; Siebenlist, U.; Chan, Y.R.; Gaffen, S.L. Interleukin-17-Induced Protein Lipocalin 2 Is Dispensable for Immunity to Oral Candidiasis. Infect. Immun. 2014, 82, 1030-1035. [CrossRef]

99. Sanal, O.; Jing, H.E.; Ozgur, T.; Ayvaz, D.; Strauss-Albee, D.M.; Ersoy-Evans, S.; Tezcan, I.; Turkkani, G.; Matthews, H.F.; Haliloglu, G.; et al. Additional Diverse Findings Expand the Clinical Presentation of DOCK8 Deficiency. J. Clin. Immunol. 2012, 32, 698-708. [CrossRef] 
100. Edgerton, M.; Koshlukova, S.E.; Araujo, M.W.B.; Patel, R.C.; Dong, J.; Bruenn, J.A. Salivary histatin 5 and human neutrophil defensin 1 kill Candida albicans via shared pathways. Antimicrob. Agents Chemother. 2000, 44, 3310-3316. [CrossRef]

101. Huppler, A.R.; Conti, H.R.; Hernandez-Santos, N.; Darville, T.; Biswas, P.S.; Gaffen, S.L. Role of Neutrophils in IL-17-Dependent Immunity to Mucosal Candidiasis. J. Immunol. 2014, 192, 1745-1752. [CrossRef]

102. Trautwein-Weidner, K.; Gladiator, A.; Nur, S.; Diethelm, P.; LeibundGut-Landmann, S. IL-17-mediated antifungal defense in the oral mucosa is independent of neutrophils. Mucosal Immunol. 2015, 8, 221-231. [CrossRef] [PubMed]

103. Marks, B.R.; Nowyhed, H.N.; Choi, J.Y.; Poholek, A.C.; Odegard, J.M.; Flavell, R.A.; Craft, J. Thymic self-reactivity selects natural interleukin 17-producing $\mathrm{T}$ cells that can regulate peripheral inflammation. Nat. Immunol. 2009, 10, 1125-1132. [CrossRef] [PubMed]

104. Zuniga, L.A.; Jain, R.; Haines, C.; Cua, D.J. Th17 cell development: From the cradle to the grave. Immunol. Rev. 2013, 252, 78-88. [CrossRef] [PubMed]

105. Tanaka, S.; Yoshimoto, T.; Naka, T.; Nakae, S.; Iwakura, Y.; Cua, D.; Kubo, M. Natural Occurring IL-17 Producing T Cells Regulate the Initial Phase of Neutrophil Mediated Airway Responses. J. Immunol. 2009, 183, 7523-7530. [CrossRef] [PubMed]

106. Jenkinson, W.E.; McCarthy, N.I.; Dutton, E.E.; Cowan, J.E.; Parnell, S.M.; White, A.J.; Anderson, G. Natural Th17 cells are critically regulated by functional medullary thymic microenvironments. J. Autoimmun. 2015, 63, 13-22. [CrossRef]

107. Massot, B.; Michel, M.L.; Diem, S.; Ohnmacht, C.; Latour, S.; Dy, M.; Eberl, G.; Leite-de-Moraes, M.C. TLR-Induced Cytokines Promote Effective Proinflammatory Natural Th17 Cell Responses. J. Immunol. 2014, 192, 5635-5642. [CrossRef]

108. Hernandez-Santos, N.; Wiesner, D.L.; Fites, J.S.; McDermott, A.J.; Warner, T.; Wuthrich, M.; Klein, B.S. Lung Epithelial Cells Coordinate Innate Lymphocytes and Immunity against Pulmonary Fungal Infection. Cell Host Microbe 2018, 23, 511. [CrossRef]

109. Haas, W.; Pereira, P.; Tonegawa, S. GAMMA-DELTA Cells. Annu. Rev. Immunol. 1993, 11, 637-685. [CrossRef]

110. Chien, Y.H.; Meyer, C.; Bonneville, M. Gamma delta T Cells: First Line of Defense and Beyond. Annu. Rev. Immunol. 2014, 32, 121-155. [CrossRef]

111. Vantourout, P.; Hayday, A. Six-of-the-best: Unique contributions of gamma delta T cells to immunology. Nat. Rev. Immunol. 2013, 13,88-100. [CrossRef]

112. Munoz-Ruiz, M.; Sumaria, N.; Pennington, D.J.; Silva-Santos, B. Thymic Determinants of gamma delta T Cell Differentiation. Trends Immunol. 2017, 38, 336-344. [CrossRef] [PubMed]

113. Hovav, A.H.; Wilharm, A.; Barel, O.; Prinz, I. Development and Function of gamma delta T Cells in the Oral Mucosa. J. Dent. Res. 2020, 99, 498-505. [CrossRef] [PubMed]

114. Wilharm, A.; Tabib, Y.; Nassar, M.; Reinhardt, A.; Mizraji, G.; Sandrock, I.; Heyman, O.; Barros-Martins, J.; Aizenbud, Y.; Khalaileh, A.; et al. Mutual interplay between IL-17-producing gamma delta T cells and microbiota orchestrates oral mucosal homeostasis. Proc. Natl. Acad. Sci. USA 2019, 116, 2652-2661. [CrossRef]

115. Fenoglio, D.; Poggi, A.; Catellani, S.; Battaglia, F.; Ferrera, A.; Setti, M.; Murdaca, G.; Zocchi, M.R. V delta 1 T lymphocytes producing IFN-gamma and IL-17 are expanded in HIV-1-infected patients and respond to Candida albicans. Blood 2009, 113, 6611-6618. [CrossRef]

116. Maher, C.O.; Dunne, K.; Comerford, R.; O’Dea, S.; Loy, A.; Woo, J.; Rogers, T.R.; Mulcahy, F.; Dunne, P.J.; Doherty, D.G. Candida albicans Stimulates IL-23 Release by Human Dendritic Cells and Downstream IL-17 Secretion by V delta 1 T Cells. J. Immunol. 2015, 194, 5953-5960. [CrossRef] [PubMed]

117. Itohara, S.; Farr, A.G.; Lafaille, J.J.; Bonneville, M.; Takagaki, Y.; Haas, W.; Tonegawa, S. Homing of a gamma-delta thymocyte subset with homogeneous t-cell receptors to mucosal epithelia. Nature 1990, 343, 754-757. [CrossRef]

118. Prinz, I. Dynamics of the interaction of gamma delta T cells with their neighbors in vivo. Cell. Mol. Life Sci. 2011, 68, 2391-2398. [CrossRef]

119. Martin, B.; Hirota, K.; Cua, D.J.; Stockinger, B.; Veldhoen, M. Interleukin-17-Producing gamma delta T Cells Selectively Expand in Response to Pathogen Products and Environmental Signals. Immunity 2009, 31, 321-330. [CrossRef] 
120. Sutton, C.E.; Lalor, S.J.; Sweeney, C.M.; Brereton, C.F.; Lavelle, E.C.; Mills, K.H.G. Interleukin-1 and IL-23 Induce Innate IL-17 Production from gamma delta T Cells, Amplifying Th17 Responses and Autoimmunity. Immunity 2009, 31, 331-341. [CrossRef]

121. Monin, L.; Ushakov, D.S.; Arnesen, H.; Bah, N.; Jandke, A.; Munoz-Ruiz, M.; Carvalho, J.; Joseph, S.; Almeida, B.C.; Green, M.J.; et al. Gamma delta T cells compose a developmentally regulated intrauterine population and protect against vaginal candidiasis. Mucosal Immunol. 2020. [CrossRef]

122. Ramani, K.; Jawale, C.V.; Verma, A.H.; Coleman, B.M.; Kolls, J.K.; Biswas, P.S. Unexpected kidney-restricted role for IL-17 receptor signaling in defense against systemic Candida albicans infection. JCI Insight 2018, 3, e98241. [CrossRef] [PubMed]

123. Kashem, S.W.; Kaplan, D.H. Skin Immunity to Candida albicans. Trends Immunol. 2016, 37, 440-450. [CrossRef] [PubMed]

124. Kashem, S.W.; Riedl, M.S.; Yao, C.; Honda, C.N.; Vulchanova, L.; Kaplan, D.H. Nociceptive Sensory Fibers Drive Interleukin-23 Production from CD301b(+) Dermal Dendritic Cells and Drive Protective Cutaneous Immunity. Immunity 2015, 43, 515-526. [CrossRef]

125. Rossjohn, J.; Pellicci, D.G.; Patel, O.; Gapin, L.; Godfrey, D.I. Recognition of CD1d-restricted antigens by natural killer T cells. Nat. Rev. Immunol. 2012, 12, 845-857. [CrossRef] [PubMed]

126. Brennan, P.J.; Brigl, M.; Brenner, M.B. Invariant natural killer T cells: An innate activation scheme linked to diverse effector functions. Nat. Rev. Immunol. 2013, 13, 101-117. [CrossRef]

127. Gumperz, J.E.; Miyake, S.; Yamamura, T.; Brenner, M.B. Functionally distinct subsets of CD1d-restricted natural killer T cells revealed by CD1d tetramer staining. J. Exp. Med. 2002, 195, 625-636. [CrossRef]

128. Coquet, J.M.; Chakravarti, S.; Kyparissoudis, K.; McNab, F.W.; Pitt, L.A.; McKenzie, B.S.; Berzins, S.P.; Smyth, M.J.; Godfrey, D.I. Diverse cytokine production by NKT cell subsets and identification of an IL-17-producing CD4(-)NK1.1(-) NKT cell population. Proc. Natl. Acad. Sci. USA 2008, 105, 11287-11292. [CrossRef]

129. Lee, Y.J.; Starrett, G.J.; Lee, S.T.; Yang, R.D.; Henzler, C.M.; Jameson, S.C.; Hogquist, K.A. Lineage-Specific Effector Signatures of Invariant NKT Cells Are Shared amongst gamma delta T, Innate Lymphoid, and Th Cells. J. Immunol. 2016, 197, 1460-1470. [CrossRef]

130. Georgiev, H.; Ravens, I.; Benarafa, C.; Forster, R.; Bernhardt, G. Distinct gene expression patterns correlate with developmental and functional traits of iNKT subsets. Nat. Commun. 2016, 7, 13116. [CrossRef]

131. Engel, I.; Seumois, G.; Chavez, L.; Samaniego-Castruita, D.; White, B.; Chawla, A.; Mock, D.; Vijayanand, P.; Kronenberg, M. Innate-like functions of natural killer $\mathrm{T}$ cell subsets result from highly divergent gene programs. Nat. Immunol. 2016, 17, 728. [CrossRef]

132. Godfrey, D.I.; Stankovic, S.; Baxter, A.G. Raising the NKT cell family. Nat. Immunol. 2010, 11, $197-206$. [CrossRef] [PubMed]

133. Lee, P.T.; Benlagha, K.; Teyton, L.; Bendelac, A. Distinct functional lineages of human V alpha-24 natural killer T cells. J. Exp. Med. 2002, 195, 637-641. [CrossRef] [PubMed]

134. Moreira-Teixeira, L.; Resende, M.; Coffre, M.; Devergne, O.; Herbeuval, J.P.; Hermine, O.; Schneider, E.; Rogge, L.; Ruemmele, F.M.; Dy, M.; et al. Proinflammatory Environment Dictates the IL-17-Producing Capacity of Human Invariant NKT Cells. J. Immunol. 2011, 186, 5758-5765. [CrossRef] [PubMed]

135. Cohen, N.R.; Tatituri, R.V.V.; Rivera, A.; Watts, G.F.M.; Kim, E.Y.; Chiba, A.; Fuchs, B.B.; Mylonakis, E.; Besra, G.S.; Levitz, S.M.; et al. Innate Recognition of Cell Wall beta-Glucans Drives Invariant Natural Killer T Cell Responses against Fungi. Cell Host Microbe 2011, 10, 437-450. [CrossRef]

136. Shimamura, M.; Yamamura, M.; Nabeshima, T.; Kitano, N.; van den Elzen, P.; Yesilkaya, H.; Andrew, P.; Illarionov, P. Activation of invariant natural killer T cells stimulated with microbial alpha-mannosyl glycolipids. Sci. Rep. 2017, 7, 9703. [CrossRef]

137. Tarumoto, N.; Kinjo, Y.; Ueno, K.; Okawara, A.; Watarai, H.; Taniguchi, M.; Maesaki, S.; Miyazaki, Y. A Limited Role of iNKT Cells in Controlling Systemic Candida albicans Infections. Jpn. J. Infect. Dis. 2012, 65, 522-526. [CrossRef]

138. Spits, H.; Artis, D.; Colonna, M.; Diefenbach, A.; di Santo, J.P.; Eberl, G.; Koyasu, S.; Locksley, R.M.; McKenzie, A.N.J.; Mebius, R.E.; et al. Innate lymphoid cells-A proposal for uniform nomenclature. Nat. Rev. Immunol. 2013, 13, 145-149. [CrossRef]

139. Eberl, G.; Colonna, M.; di Santo, J.P.; McKenzie, A.N.J. Innate lymphoid cells: A new paradigm in immunology. Science 2015, 348, aaa6566. [CrossRef] 
140. Gladiator, A.; Wangler, N.; Trautwein-Weidner, K.; LeibundGut-Landmann, S. Cutting Edge: IL-17-Secreting Innate Lymphoid Cells Are Essential for Host Defense against Fungal Infection. J. Immunol. 2013, 190, 521-525. [CrossRef]

141. Sparber, F.; Dolowschiak, T.; Mertens, S.; Lauener, L.; Clausen, B.E.; Joller, N.; Stoitzner, P.; Tussiwand, R.; LeibundGut-Landmann, S. Langerin(+) DCs regulate innate IL-17 production in the oral mucosa during Candida albicans-mediated infection. PLoS Pathog. 2018, 14, e1007069. [CrossRef]

142. Corte, L.; Roscini, L.; Colabella, C.; Tascini, C.; Leonildi, A.; Sozio, E.; Menichetti, F.; Merelli, M.; Scarparo, C.; Meyer, W.; et al. Exploring ecological modelling to investigate factors governing the colonization success in nosocomial environment of Candida albicans and other pathogenic yeasts. Sci. Rep. 2016, 6, 26860. [CrossRef] [PubMed]

143. Cavalheiro, M.; Teixeira, M.C. Candida Biofilms: Threats, Challenges, and Promising Strategies. Front. Med. 2018, 5, 28. [CrossRef] [PubMed]

144. Alves, R.; Barata-Antunes, C.; Casal, M.; Brown, A.J.P.; van Dijck, P.; Paiva, S. Adapting to survive: How Candida overcomes host-imposed constraints during human colonization. PLoS Pathog. 2020, 16, e1008478. [CrossRef] [PubMed]

145. Sharafutdinov, I.S.; Ozhegov, G.D.; Sabirova, A.E.; Novikova, V.V.; Lisovskaya, S.A.; Khabibrakhmanova, A.M.; Kurbangalieva, A.R.; Bogachev, M.I.; Kayumov, A.R. Increasing Susceptibility of Drug-Resistant Candida albicans to Fluconazole and Terbinafine by 2(5H)-Furanone Derivative. Molecules 2020, 25, 642. [CrossRef]

146. Haqshenas, G.; Doerig, C. Targeting of host cell receptor tyrosine kinases by intracellular pathogens. Sci. Signal. 2019, 12, eaau9894. [CrossRef]

147. Ho, J.; Moyes, D.L.; Tavassoli, M.; Naglik, J.R. The Role of ErbB Receptors in Infection. Trends Microbiol. 2017, 25, 942-952. [CrossRef]

148. Vrijens, P.; Noppen, S.; Boogaerts, T.; Vanstreels, E.; Ronca, R.; Chiodelli, P.; Laporte, M.; Vanderinden, E.; Liekens, S.; Stevaert, A.; et al. Influenza virus entry via the GM3 ganglioside-mediated platelet-derived growth factor receptor beta signalling pathway. J. Gen. Virol. 2019, 100, 583-601. [CrossRef]

149. Wu, S.Y.; Zhang, Q.; Zhang, F.; Meng, F.S.; Liu, S.D.; Zhou, R.Y.; Wu, Q.Z.; Li, X.R.; Shen, L.; Huang, J.; et al. HER2 recruits AKT1 to disrupt STING signalling and suppress antiviral defence and antitumour immunity. Nat. Cell Biol. 2019, 21, 1027. [CrossRef]

150. Radoshevich, L.; Cossart, P. Listeria monocytogenes: Towards a complete picture of its physiology and pathogenesis. Nat. Rev. Microbiol. 2018, 16, 32-46. [CrossRef]

151. Weinkauf, C.; Salvador, R.; PereiraPerrin, M. Neurotrophin Receptor TrkC Is an Entry Receptor for Trypanosoma cruzi in Neural, Glial, and Epithelial Cells. Infect. Immun. 2011, 79, 4081-4087. [CrossRef]

152. Wroblewski, L.E.; Peek, R.M.; Wilson, K.T. Helicobacter pylori and Gastric Cancer: Factors That Modulate Disease Risk. Clin. Microbiol. Rev. 2010, 23, 713-739. [CrossRef] [PubMed]

153. Amieva, M.; Peek, R.M. Pathobiology of Helicobacter pylori-Induced Gastric Cancer. Gastroenterology 2016, 150, 64-78. [CrossRef] [PubMed]

154. Sharafutdinov, I.; Backert, S.; Tegtmeyer, N. Cortactin: A Major Cellular Target of the Gastric Carcinogen Helicobacter pylori. Cancers 2020, 12, 159. [CrossRef] [PubMed]

155. Norgaard, M.; Thomsen, R.W.; Farkas, D.K.; Mogensen, M.F.; Sorensen, H.T. Candida infection and cancer risk: A Danish nationwide cohort study. Eur. J. Intern. Med. 2013, 24, 451-455. [CrossRef] [PubMed]

156. Chung, L.M.; Liang, J.A.; Lin, C.L.; Sun, L.M.; Kao, C.H. Cancer risk in patients with candidiasis: A nationwide population-based cohort study. Oncotarget 2017, 8, 63562-63573. [CrossRef]

157. Ramirez-Garcia, A.; Rementeria, A.; Aguirre-Urizar, J.M.; Moragues, M.D.; Antoran, A.; Pellon, A.; Abad-Diaz-de-Cerio, A.; Hernando, F.L. Candida albicans and cancer: Can this yeast induce cancer development or progression? Crit. Rev. Microbiol. 2016, 42, 181-193. [CrossRef] [PubMed]

158. Kazmierczak-Siedlecka, K.; Dvorak, A.; Folwarski, M.; Daca, A.; Przewlocka, K.; Makarewicz, W. Fungal Gut Microbiota Dysbiosis and Its Role in Colorectal, Oral, and Pancreatic Carcinogenesis. Cancers 2020, 12, 1326. [CrossRef]

159. Tabarkiewicz, J.; Pogoda, K.; Karczmarczyk, A.; Pozarowski, P.; Giannopoulos, K. The Role of IL-17 and Th17 Lymphocytes in Autoimmune Diseases. Arch. Immunol. Et Ther. Exp. 2015, 63, 435-449. [CrossRef]

160. Bernardini, N.; Skroza, N.; Tolino, E.; Mambrin, A.; Anzalone, A.; Balduzzi, V.; Colapietra, D.; Marchesiello, A.; Michelini, S.; Proietti, I.; et al. IL-17 and its role in inflammatory, autoimmune, and oncological skin diseases: State of art. Int. J. Dermatol. 2020, 59, 406-411. [CrossRef] 
161. Beringer, A.; Miossec, P. IL-17 and IL-17-producing cells and liver diseases, with focus on autoimmune liver diseases. Autoimmun. Rev. 2018, 17, 1176-1185. [CrossRef]

162. Kuwabara, T.; Ishikawa, F.; Kondo, M.; Kakiuchi, T. The Role of IL-17 and Related Cytokines in Inflammatory Autoimmune Diseases. Mediat. Inflamm. 2017, 2017, 1-11. [CrossRef] [PubMed]

(C) 2020 by the authors. Licensee MDPI, Basel, Switzerland. This article is an open access article distributed under the terms and conditions of the Creative Commons Attribution (CC BY) license (http://creativecommons.org/licenses/by/4.0/). 